\title{
Perancangan Ruang Terbuka Hijau pada Lahan Tempat Pembuangan Akhir Sampah Pasca Operasi Pasir Impun untuk Membentuk Partisipasi Masyarakat
}

\author{
Esti Galuh Arini ${ }^{1}$ \\ ${ }^{1}$ Staf Pengajar Perencanaan Wilayah dan Kota ITSB, Deltamas \\ e-mail: estigaluharini@yahoo.com
}

\begin{abstract}
Abstrak
Penelitian ini merupakan salah satu contoh perancangan Ruang Terbuka Hijau (RTH) Kota dengan mempertimbangkan pendapat masyarakat dalam prosesnya dan mendorong tumbuhnya partisipasi dari masyarakat itu sendiri sebagai tujuan akhir. Sebagai studi kasus diambil lahan Tempat Pembuangan Akhir Sampah (TPA) Pasca Operasi, Pasir Impun di Kota Bandung. Dengan tujuan untuk menambah luasan RTH, dalam Renstra 2004-2009, salah satu program yang direncanakan adalah melakukan penataan ulang TPA Pasca Operasi, Pasir Impun, di wilayah Bandung Timur. Dari segi kelayakan teknis, lahan Tempat Pembuangan Akhir Sampah yang menerapkan sistem sanitary landfill ini dinilai paling siap untuk dialihfungsikan. Sedangkan dari segi sosial, lahan ini dikelilingi permukiman penduduk yang cukup padat (1.254 jiwa penduduk) yang belum memiliki ruang terbuka publik yang bisa dimanfaatkan masyarakat untuk berekreasi atau untuk melakukan aktivitas sosial kemasyarakatan lainnya, sehingga lahan Tempat Pembuangan Akhir Sampah Pasca Operasi, Pasir Impun seluas $\pm 4,1 \mathrm{Ha}$ ini dinilai memiliki potensi yang cukup besar untuk dikembangkan sebagai Ruang Terbuka Hijau Lingkungan. Pendekatan desain yang dipilih adalah pendekatan dengan mempertimbangkan pendapat masyarakat. Diharapkan dengan pendekatan ini, hasil perancangan Ruang Terbuka Hijau Lingkungan pada lahan Tempat Pembuangan Akhir Sampah Pasca Operasi Pasir Impun bisa merespon kebutuhan dasar masyarakat yang sebenarnya dan pada akhirnya bisa menjamin kesuksesan dari alih fungsi lahan serta keberlanjutan program yang direncanakan. Proses desain dimulai dengan melakukan survei langsung ke lahan dan permukiman di sekitarnya, wawancara dengan pihak-pihak terkait, pembagian kuesioner kepada masyarakat, serta studi pustaka dan preseden. Selanjutnya, dilakukan analisis dari kegiatan-kegiatan tersebut untuk menyusun dan merumuskan program ruang dan kriteria desain sebagai landasan untuk desain yang akan dibuat atau dikembangkan. Hasil akhir proses desain ini berupa simulasi perancangan Ruang Terbuka Hijau Lingkungan pada lahan TPA Pasca Operasi Pasir Impun.
\end{abstract}

\begin{abstract}
This research is an example of designing City Green Open Space (RTH) by considering community opinion in the process and encouraging the growth of participation from the community itself as the ultimate goal. As a case study, Pasir Impun post-operation landfill (TPA) in Bandung City was taken. With the aim of increasing the area of RTH, in Bandung Strategic Plan 2004-2009, one of the planned programs was to re-arrange the Post-Operation Landfill, Pasir Impun, in the East Bandung. In terms of technical feasibility, Pasir Impun post-operation landfill is considered the most ready to be converted, Whereas from a social standpoint, this landfill is surrounded by fairly dense residential areas (1,254 inhabitants), who do not have public open spaces that can be used by the community for recreation or other social activities, so that the Pasir Impun post-operation landfill with an area of $\pm 4.1 \mathrm{Ha}$ is considered to have great potential to be developed as an local Green Open Space. It is expected that with this approach, the results of the design of Green Open Space on the Post-Operation Landfill Pasir Impun, can answer the basic needs of the community and in the end can guarantee the success of land conversion and the program sustainability. The design process begins by conducting a survey directly to the land and surrounding settlements, interviews with relevant parties, distributing questionnaires to the community, as well as literature and precedents. Furthermore, an analysis of these activities is carried out to compile and formulate a space program and design criteria as the basis for the design that will be created or developed. The final result of this design process is a design simulation of local open space on the Pasir Impun post-operation landfill.
\end{abstract}

Kata kunci: RTH lingkungan, TPA pasca operasi, sanitary landfill, partisipasi masyarakat 


\section{PENDAHULUAN}

TPA Pasir Impun yang diresmikan pada tanggal 4 April 1987 ini, merupakan proyek TPA percobaan dan percontohan yang menerapkan metode lahan-urug saniter (sanitary landfill), meski pengurugannya masih belum sempurna. la dirancang untuk melayani wilayah Bandung Timur (Ujung Berung, Arcamanik dan Cibiru) Luas penimbunannya mencapai $17.500 \mathrm{~m}^{2}$, dengan luas total TPA (berikut sarana pendukungnya) mencapai 3,6 ha. Kapasitas menampung sampahnya $\pm 5000 \mathrm{~m}^{3} /$ hari.

Setelah 13 tahun beroperasi, sekitar tahun 1999 TPA Pasir Impun ditutup. Saat peristiwa longsor TPA Leuwigajah pada pertengahan tahun 2005, rencananya TPA pasca operasi Pasir Impun akan dioperasikan lagi. Namun, rencana ini mendapat penolakan keras dari masyarakat yang bermukim di sekitar lahan TPA, sehingga lahan TPA pasca operasi Pasir Impun ini batal difungsikan kembali. Lahan TPA pasca operasi Pasir Impun yang sudah direklamasi ini, mulai dihijaukan dengan perencanaan dan penataan kembali oleh Pemerintah Kota Bandung.

Pemerintah Kota Bandung bidang Pertamanan dan Estetika Kota merumuskan strategi untuk memelihara, mempertahankan (preservasi), dan memperluas RTH yang tertuang dalam Rencana Strategis Pemerintah Kota Bandung Tahun 20042009: Program Penataan dan Penghijauan Kawasan Bandung Timur dan Bandung Utara.

Dalam program tersebut Pemerintah Kota Bandung merencanakan penataan ulang lahan TPA pasca operasi Pasir Impun $(4,1 \mathrm{Ha})$ Kecamatan Cicadas dan Cicabe $(4,4 \mathrm{Ha})$ Wilayah Ujungberung dengan anggaran dana sekitar Rp 800 juta. Rencana penataan lahan TPA pasca operasi Pasir Impun ini sudah dibuat oleh Pemerintah Kota Bandung dalam bentuk DED (Detail Engineering Design) dengan pemanfaatan lahan sebagai hutan kota.

Permasalahan-permasalahan yang tak hanya teknis tapi juga sosial mulai muncul terkait dengan fungsi lahan sebelumnya sebagai TPA. Permasalahan sosial yang terkait, antara lain persepsi negatif masyarakat terhadap lahan TPA itu sendiri.
Saat masih beroperasi, lahan TPA menjadi suatu lokasi yang dijauhi karena kondisinya yang bau, kotor, dan secara estetika kurang sedap dipandang. Setelah selesai beroperasi pun, pemanfaatan lahan ini kurang optimal karena perencanaan yang kurang tepat. Alih fungsi lahan TPA pasca operasi menjadi RTH merupakan upaya dalam membentuk lingkungan yang lebih baik dan membawa perubahan positif dalam cara hidup penduduk kota.

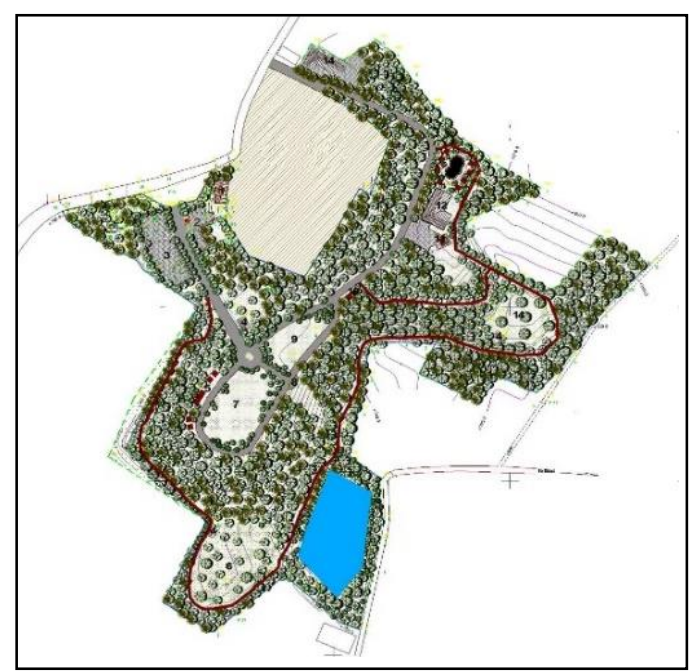

Gambar 1. Site plan hutan kota di lahan TPA pasca operasi Pasir Impun yang direncanakan Pemkot Bandung.

Sumber: Konsultan Perencana DED Pasir Impun

Fasilitas yang dirancang dalam lahan TPA pasca operasi Pasir Impun direncanakan berdasarkan permintaan pemberi tugas, yaitu Pemerintah Kota Bandung. Padahal, aspek sosial dari perancangan RTH merupakan aspek yang tidak kalah penting dibandingkan dengan aspek yang bersifat teknis dan fungsional, dan salah satu faktor yang menentukan keberhasilan pembangunan sebuah RTH adalah keterlibatan atau partisipasi masyarakat.

Sudah selayaknya keinginan atau pendapat masyarakat yang bermukim di sekitar lahan TPA pasca operasi Pasir Impun menjadi bahan pertimbangan dalam perencanaan RTH karena merekalah yang nantinya akan menjadi end-user dari fasilitas ini. Bagi masyarakat, keterlibatan dalam perencanaan, pengambilan keputusan dan pelaksanaan pembangunan yang berhubungan dengan usaha memperbaiki kehidupan mereka adalah suatu kebutuhan. 
Perancangan Ruang Terbuka Hijau pada Lahan Tempat Pembuangan Akhir Sampah Pasca Operasi Pasir Impun untuk Membentuk Partisipasi Masyarakat

Selain itu, pembangunan yang mengacu pada potensi setempat (community based) merupakan kekuatan utama untuk mencapai keberhasilan. Partisipasi masyarakat sebagai stakeholder pembangunan adalah salah satu kunci dan penentu dari keberhasilan pembangunan itu sendiri.

Masalah RTH menyangkut kepentingan banyak pihak dan menjadi tanggung jawab semua pihak yang berkepentingan mulai dari Pemerintah dan masyarakat umum. Memang diperlukan komitmen bersama dari semua pihak baik Pemerintah Kota maupun masyarakat dalam upaya membangun, memelihara, dan mengelola RTH agar tetap lestari. Kata kunci keberhasilan adalah aspek koordinasi, yaitu koordinasi dari semua pihak yang terlibat.

Ketersediaan ruang terbuka di lingkungan sekitar lahan TPA Pasca Operasi Pasir Impun yang sangat terbatas atau bahkan tidak ada karena padatnya permukiman, sebenarnya membuat lahan memiliki potensi besar untuk dikembangkan sebagai ruang terbuka di tingkat komunitas/lingkungan. Apalagi ditunjang dengan bentang alam yang menarik dan pemandangan yang indah. Lahan TPA pasca operasi Pasir Impun ini bisa menjadi sebuah taman komunitas yang merupakan wadah bagi masyarakat yang bermukim di sekeliling lahan untuk beraktifitas baik secara sosial, budaya dan ekonomi.

Menyadari arti penting lahan TPA pasca operasi bagi kota Bandung pada umumnya dan masyarakat Pasir Impun pada khususnya, perlu rencana pengembangan dan penataan yang tepat. Agar lahan TPA pasca operasi Pasir Impun ini tidak hanya berfungsi sebagai kawasan lindung dan area resapan air, tapi juga menjadi tempat yang memiliki fungsi lebih, sehingga bermanfaat bagi masyarakat.

Melalui pendekatan partisipasi masyarakat pada alih fungsi lahan TPA pasca operasi menjadi $\mathrm{RTH}$, lahan dapat dikembangkan menjadi hutan kota sekaligus taman komunitas yang dapat menampung aktivitas warganya, juga memberi sumbangan dalam meningkatkan kualitas lingkungan perkotaan menjadi lebih baik. Alih fungsi lahan ini tak sekadar bertujuan untuk mereklamasi atau mengembalikan lahan ke kondisi awal dalam usaha untuk memperluas $\mathrm{RTH}$, tapi juga menciptakan dan menyediakan ruang terbuka bagi masyarakat yang dapat diarahkan untuk menampung kegiatan sosial, budaya, ekonomi dan lain-lain. Pada akhirnya, secara fisik RTH dapat melindungi tata air dan keanekaragaman hayati serta menjamin keberlanjutan wilayah kota sekaligus menambah nilai kualitas lingkungan dan budaya kota tersebut. Sistem RTH yang baik akan menyeimbangkan lingkungan perkotaan.

\section{PERMASALAHAN}

Lahan TPA pasca operasi Pasir Impun dan permukiman di sekelilingnya dipilih sebagai fokus studi dan penelitian sebab lokasinya masih berada di wilayah Kotamadya Bandung (konteks perkotaan). Dalam konteks kota, lahan TPA pasca operasi yang belum termanfaatkan dengan baik ini memiliki potensi sebagai kontributor dalam menambah luas RTH Kota Bandung yang masih minim.

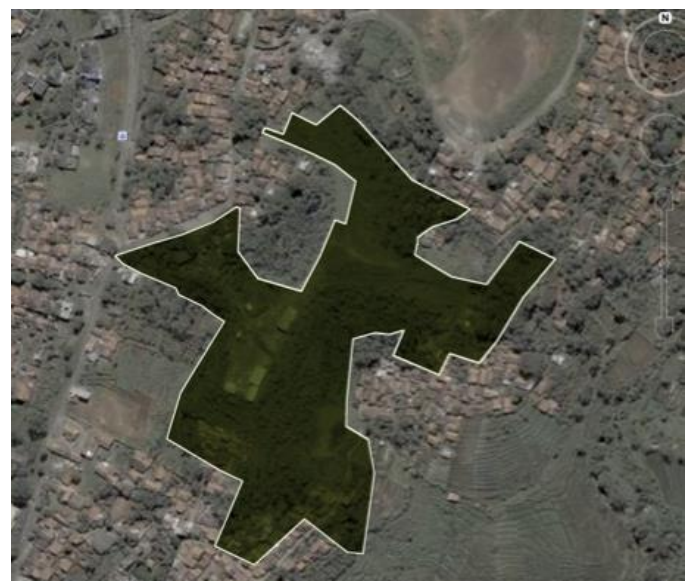

Gambar 2. Lahan perencanaan TPA Pasca Operasi Pasir dikelilingi permukiman penduduk yang padat

Dari segi teknis, kesiapan lahan TPA pasca operasi Pasir Impun untuk digunakan dan dibangun kembali paling siap dibanding dengan TPA lainnya (Cicabe). TPA Pasir Impun sudah berhenti beroperasi sejak Februari 1999 dan pengurugan sampahnya sudah menggunakan sistem sanitary landfill.

Meskipun demikian, masih terdapat beberapa kendala teknis yang dihadapi saat mengalihfungsikannya menjadi sebuah RTH, yaitu:

Kestabilan lahan dan kemungkinan settlement (penurunan tanah) 
- Pencemaran air tanah oleh aliran dan rembesan lindi (leachte)

- Masalah bau dan potensi terbakar/meledak dengan adanya gas Metana $\left(\mathrm{CH}_{4}\right)$ dari bekas timbunan sampah

- Kesuburan dan keamanan tanah penutup (cover) sanitary landfill dari zat-zat pencemar Masalah lain yang muncul pada tahap perencanaan adalah Pemerintah Kota Bandung sudah membuat perencanaan teknis sampai pada tahap DED (Detail Engineering Design) tanpa melibatkan masyarakat yang bermukim di sekitar lahan TPA pasca operasi Pasir Impun, sehingga pemanfaatan lahan bekas TPA ini cenderung belum optimal. Akibatnya, RTH yang direncanakan ini belum menjadi tempat beraktifitas yang memiliki makna dan identitas bagi masyarakat sekitar.

\section{PENGUMPULAN DATA, KAJIAN PUSTAKA \& STUDI BANDING}

Pengumpulan data primer dilakukan melalui survei observasi kondisi eksisting, lingkungan binaan dan kondisi sosial pada lahan perancangan, serta wawancara langsung pada pihak-pihak terkait (masyarakat, Dinas Pertamanan, dan lainnya).

Pengumpulan data sekunder dilakukan melalui studi literatur, rencana tata ruang kota dan peraturan/kebjakan lainnya. Selain dari instansi terkait, data sekunder juga diperoleh melalui media internet. Tahap ini dilakukan dengan mengkaji landasan teoritik perencanaan dan perancangan yang dijadikan pendekatan dalam alih fungsi lahan TPA pasca operasi menjadi RTH, serta mengkaji studi kasus sejenis terhadap proyek-proyek alih fungsi lahan TPA di kota-kota lain yang dianggap berhasil.

\section{ANALISIS KAWASAN \& TAPAK}

Untuk mengidentifikasikan potensi dan permasalahan lahan TPA pasca operasi Pasir Impun, dilakukan analisis terhadap kawasan
Pasir Impun, dengan cara mengidentifikasi kondisi dan karakteristik eksisting kawasan, potensi, permasalahan serta peluang untuk dapat melakukan rencana pengembangan.

Analisis yang digunakan dalam studi ini antara lain:

- Analisis tata ruang

- Analisis aksesibilitas kawasan

- Analisis tata guna lahan dan eksisting

- Analisis sirkulasi

- Analisis aktifitas dan kegiatan

- Analisis infrastruktur dan eksisting dalam lahan

- Analisis topografi dan kemiringan lahan

- Analisis drainase/aliran air

- Analisis vegetasi

- Analisis visual

Berdasarkan hasil analisa yang dilakukan pada tahap ini, diperoleh gambaran mengenai potensi, permasalahan serta prospek pengembangan lahan. Dengan memetakan ketiga hal tersebut maka lebih mudah untuk mengelaborasi sejumlah gagasan yang merespon ketiganya. Tanggapan ini selanjutnya akan dikembangkan menjadi konsep perancangan lahan pada tahap selanjutnya.

Tabel 1. Kesesuaian hasil analisa

\begin{tabular}{|c|c|c|c|}
\hline Analisis & Sesuai & $\begin{array}{c}\text { Sesuai tapi } \\
\text { ada } \\
\text { Perbaikan }\end{array}$ & $\begin{array}{l}\text { Tidak } \\
\text { Sesuai }\end{array}$ \\
\hline Tata ruang & $\sqrt{ }$ & & \\
\hline $\begin{array}{l}\text { Aksesibilitas } \\
\text { kawasan }\end{array}$ & $\sqrt{ }$ & & \\
\hline $\begin{array}{l}\text { Tata guna lahan } \\
\text { dan eksisting }\end{array}$ & $\sqrt{ }$ & & \\
\hline Sirkulasi & $\sqrt{ }$ & & \\
\hline $\begin{array}{l}\text { Aktifitas dan } \\
\text { kegiatan }\end{array}$ & & $\sqrt{ }$ & \\
\hline $\begin{array}{l}\text { Infrastruktur dasar } \\
\text { dan khusus }\end{array}$ & & $\sqrt{ }$ & \\
\hline $\begin{array}{l}\text { Topografi dan } \\
\text { kemiringan lahan }\end{array}$ & & $\sqrt{ }$ & \\
\hline Drainase/aliran air & & $\sqrt{ }$ & \\
\hline Vegetasi & & $\sqrt{ }$ & \\
\hline Visual & $\sqrt{ }$ & & \\
\hline
\end{tabular}

Sumber: Hasil Analisis 
Perancangan Ruang Terbuka Hijau pada Lahan Tempat Pembuangan Akhir Sampah Pasca Operasi Pasir Impun untuk Membentuk Partisipasi Masyarakat

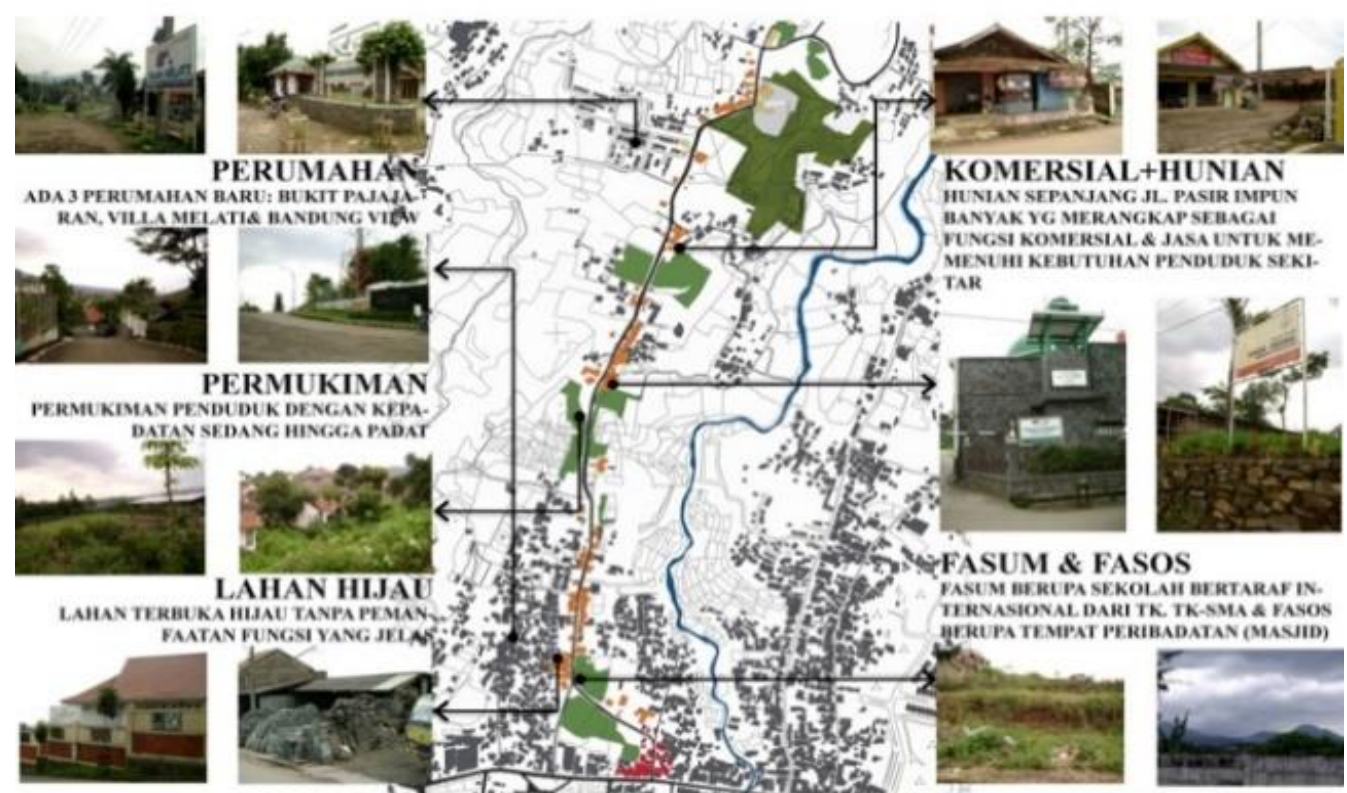

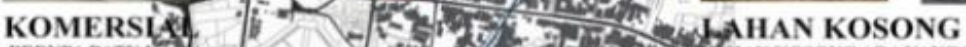

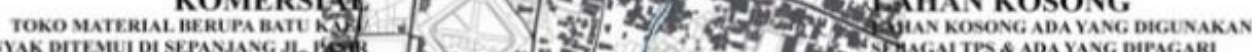

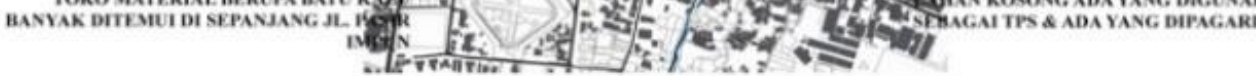

Gbr. 3. Gambaran fungsi-fungsi eksisiting di sepanjang Jl. Pasir Impun (akes utama) dan sekitar lahan TPA pasca operasi Pasir Impun

Sumber: Survei lapangan \& Analisis pribadi

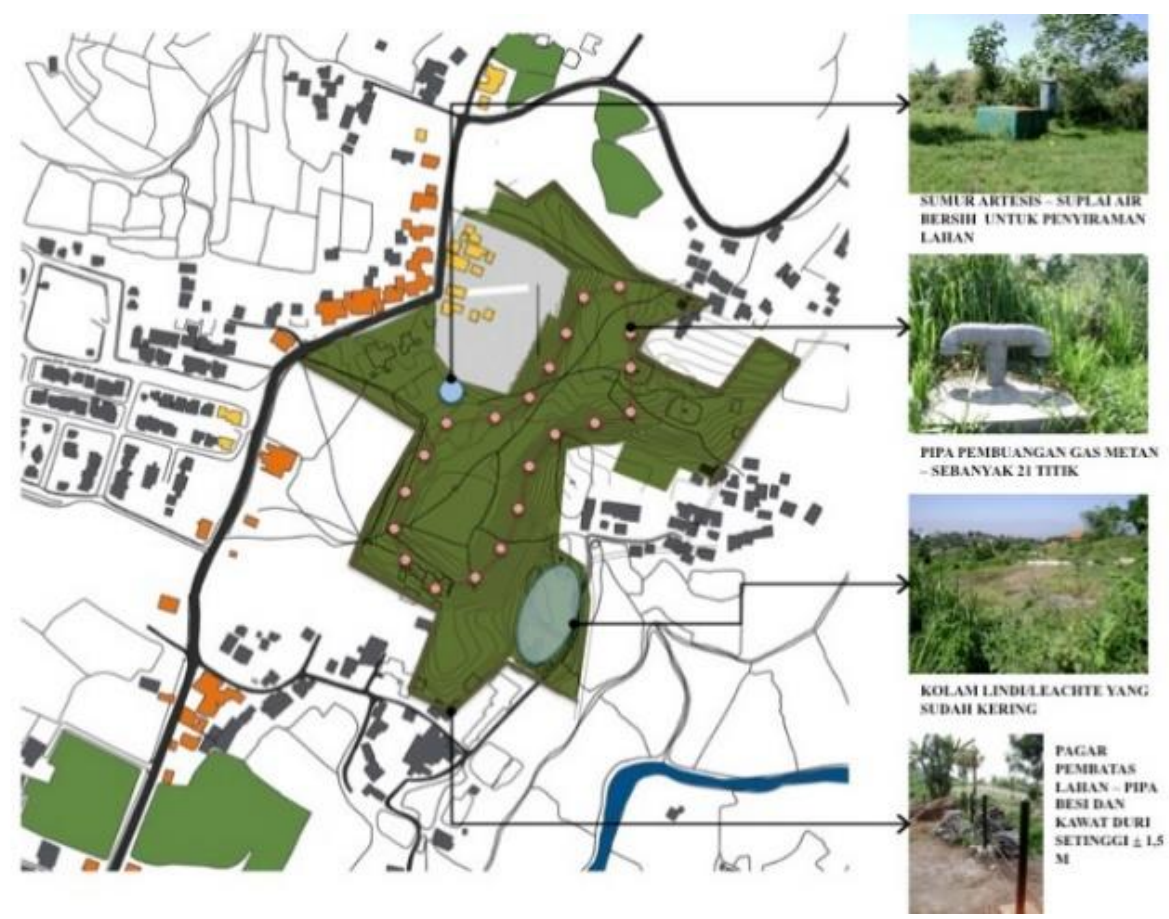

Gambar 4. Infrastruktur dasar dan khusus yang terdapat dalam lahan

Sumber: Survei lapangan 2008-2009 \& Hasil Analisa 


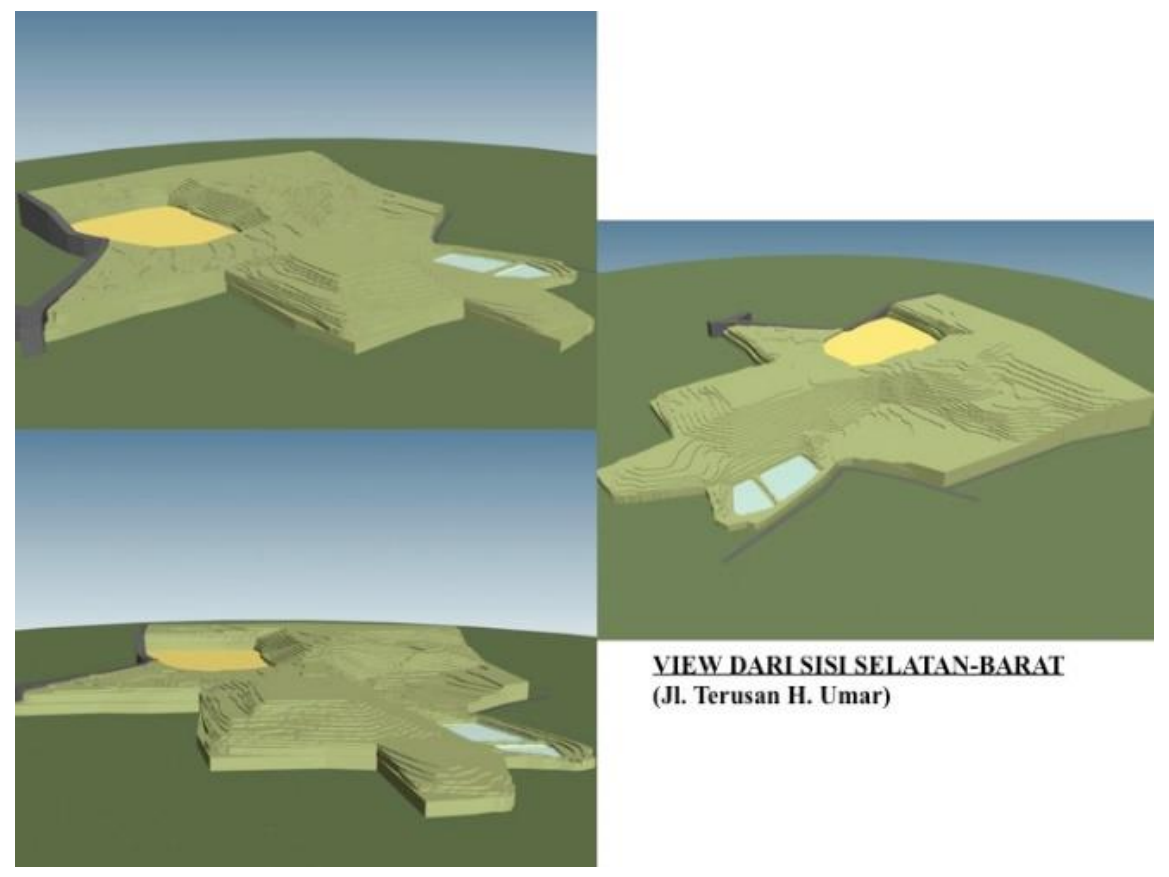

Gambar 5. View lahan dilihat dari sisi Utara - Timur Sumber: Hasil Analisis

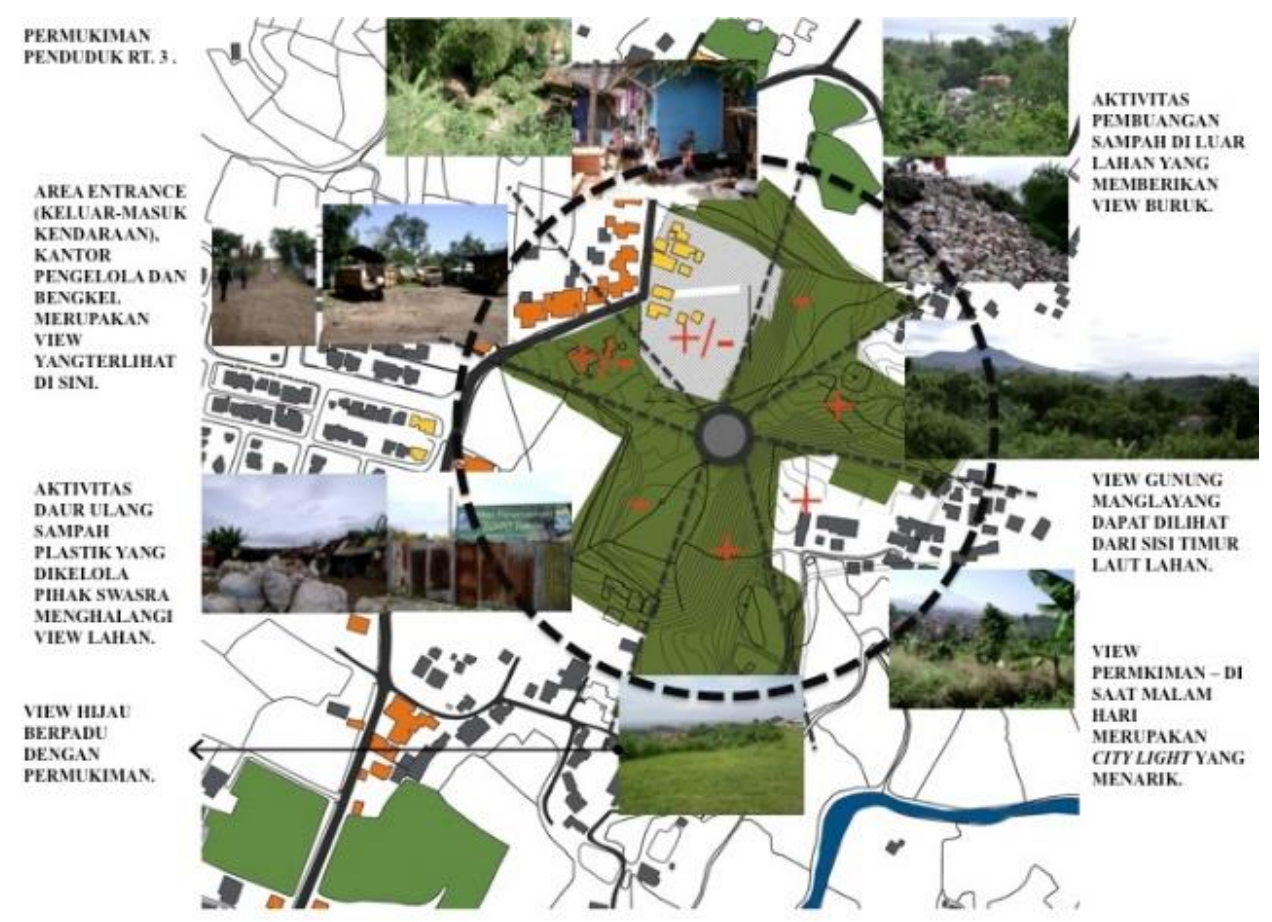

Gambar 6. Analisis view lahan TPA Pasca Operasi Pasir Impun dari berbagai arah

Sumber: Survei lapangan dan Hasil Analisis 


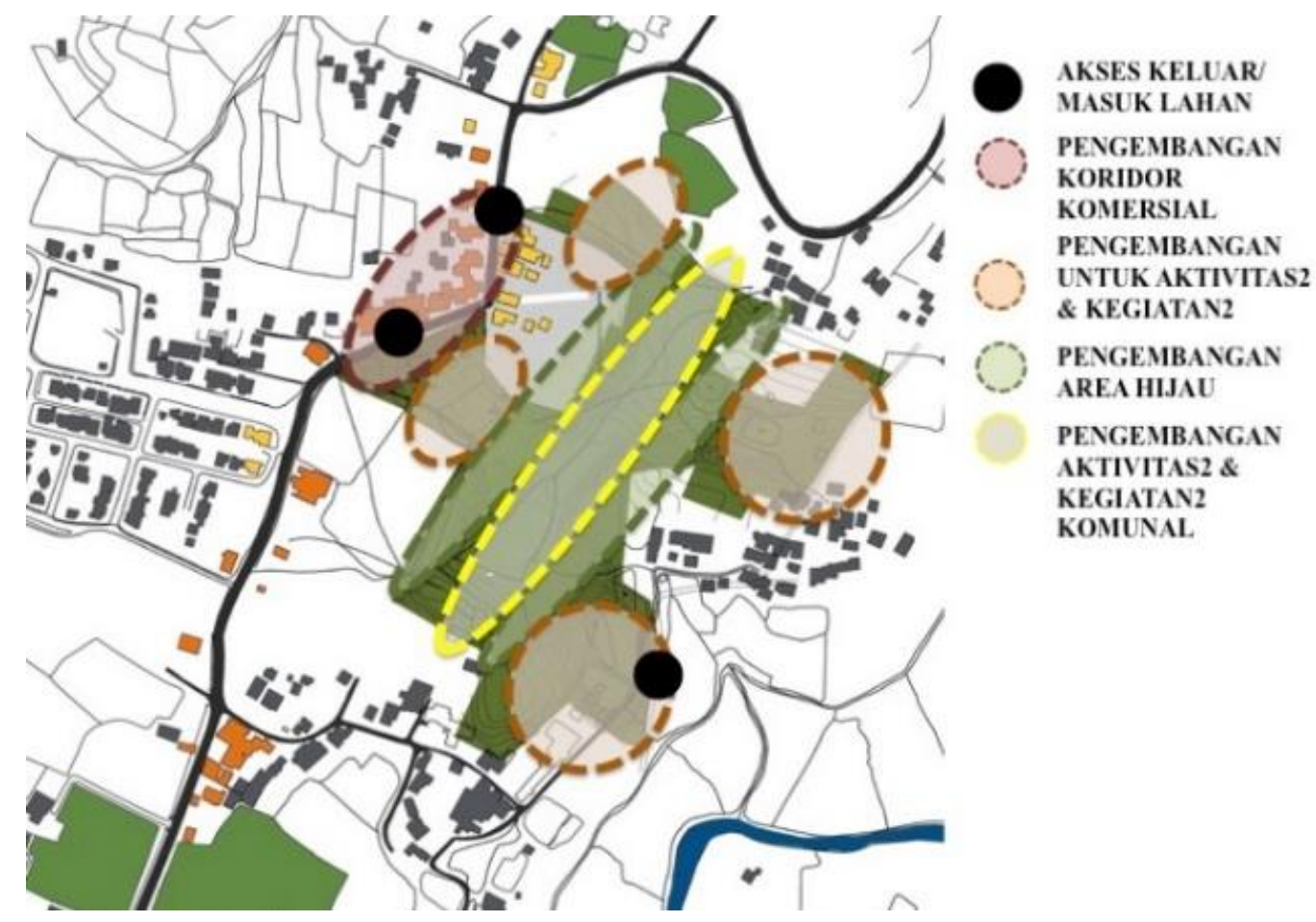

Gambar 7. Zoning gagasan awal rancangan RTH pada lahan TPA Pasca Operasi Pasir Impun

\section{PENELITIAN PERSEPSI DAN HARAPAN MASYARAKAT}

Penelitian persepsi dan harapan masyarakat bertujuan untuk merumuskan kebutuhan dan keinginan masyarakat terhadap alih fungsi lahan TPA Pasca Operasi Pasir Impun menjadi RTH Kota dengan mencari jenis aktivitas dan fasilitas yang paling sesuai dengan kebutuhan dan keinginan masyarakat.

Masyarakat yang dimaksud di sini adalah end user atau pengguna akhir lahan nantinya masyarakat yang bermukim di sekeliling lahan TPA Pasca Operasi, masyarakat yang beraktifitas dan tinggal di sekitar lahan TPA Pasca Operasi, serta masyarakat umum.

Jenis aktivitas dan fasilitas didapatkan dengan cara pengamatan langsung, wawancara tidak terstruktur di lapangan dan kuesioner. Kuesioner dibagikan kepada responden yang dianggap mewakili masyarakat sebagai end user lahan. Selanjutnya, data dari kuesioner berupa tanggapan masyarakat terhadap alih fungsi lahan, juga jenis aktivitas dan fasilitas yang dibutuhkan dan diinginkan oleh mereka diolah dan dirumuskan.

Dengan menggabungkan hasil rumusan kebutuhan dan keinginan masyarakat yang didapatkan lewat penelitian, hasil analisis pada lahan serta kajian literatur yang telah dilakukan sebelumnya, maka bisa didapatkan optimalisasi pemanfaatan dan bentuk RTH yang sesuai dengan keinginan dan kebutuhan masyarakat untuk dikembangkan pada lahan TPA Pasca Operasi Pasir Impun.

Diharapkan dengan membuat program dan kriteria desain yang sesuai dengan kebutuhan dan keinginan masyarakat sebagai end user, akan tercipta ruang publik yang:

tanggap terhadap keinginan dan kebutuhan penggunanya (responsive),

memiliki ikatan emosi dengan masyarakat setempat baik individu maupun komunal (meaningful), 
- dapat dimanfaatkan oleh seluruh lapisan masyarakat dari berbagai golongan (democratic).

Penelitian ini merupakan bentuk dari partisipasi masyarakat, pendekatan yang dipilih dalam perancangan alih fungsi lahan TPA Pasca Pasir Impun. Selain menjadi bagian dari proses, partisipasi masyarakat menjadi tujuan akhir dari proses perancangan.

Dalam penelitian harapan dan persepsi masyarakat terhadap lahan TPA Pasca Operasi Pasir Impun yang merupakan bagian dari proses perancangan, masyarakat ditanya pendapatnya dengan membagikan kuesioner. Dalam proses ini, peneliti telah melakukan bentuk partisipasi konsultatif dan masyarakat lokal berperan sebagai klien.

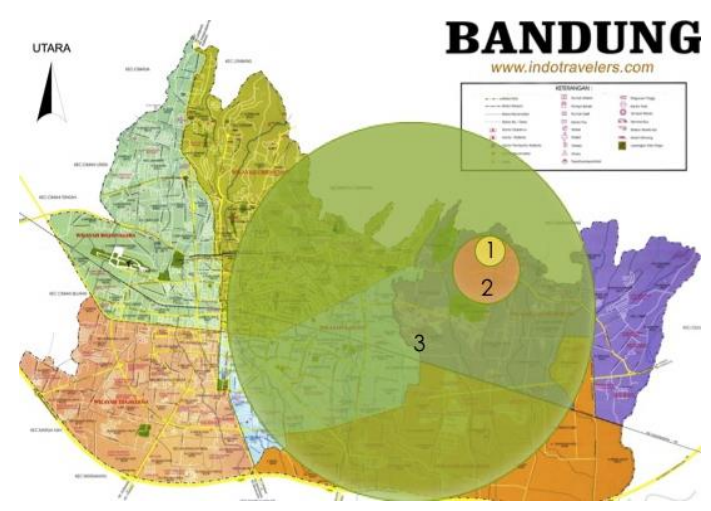

Gambar 8. Tiga kelompok masyarakat yang menjadi sampel/subyek penelitian

Sumber: www.indotravelers.com dan Hasil Analisis
Subyek/sampel penelitian yang dipilih adalah masyarakat yang dibagi dalam 3 kelompok:

1. Masyarakat Tetangga: Masyarakat yang bertetangga langsung atau bermukim di sekeliling lahan TPA Pasca Operasi Pasir Impun.

2. Masyarakat Sekitar: Masyarakat yang bertetangga tidak langsung dengan lahan TPA Pasca Operasi Pasir Impun (sepanjang jalan Pasir Impun/ \pm 2 km dari jalan arteri/Jl. Raya Ujung Berung hingga ke lahan TPA Pasca Operasi Pasir Impun).

3. Masyarakat umum: Masyarakat yang sedang beraktivitas di taman. Sampel yang diambil oleh peneliti adalah para pengguna Taman Ganesha, ITB, Bandung.

Kuesioner dibagikan kepada 50 orang responden dengan komposisi: $50 \%$ masyarakat tetangga (25 orang), 30\% masyarakat sekitar (15 orang) dan $20 \%$ masyarakat umum (10 orang).

Persepsi Masyarakat Terhadap Lahan TPA Pasca Operasi Pasir Impun

Seiring dengan selesainya masa operasi TPA Pasir Impun, masyarakat yang tadinya merasa terganggu dengan hadirnya TPA mulai merasakan jika keberadaannya jadi tidak mengganggu. Bisa diasumsikan penduduk memiliki persepsi dan image yang cukup baik pada lahan TPA Pasca Operasi Pasir Impun, sehingga tidak diperlukan strategi khusus untuk mengubah pandangan negatif masyarakat tetangga. 
Perancangan Ruang Terbuka Hijau pada Lahan Tempat Pembuangan Akhir Sampah Pasca Operasi Pasir Impun untuk Membentuk Partisipasi Masyarakat

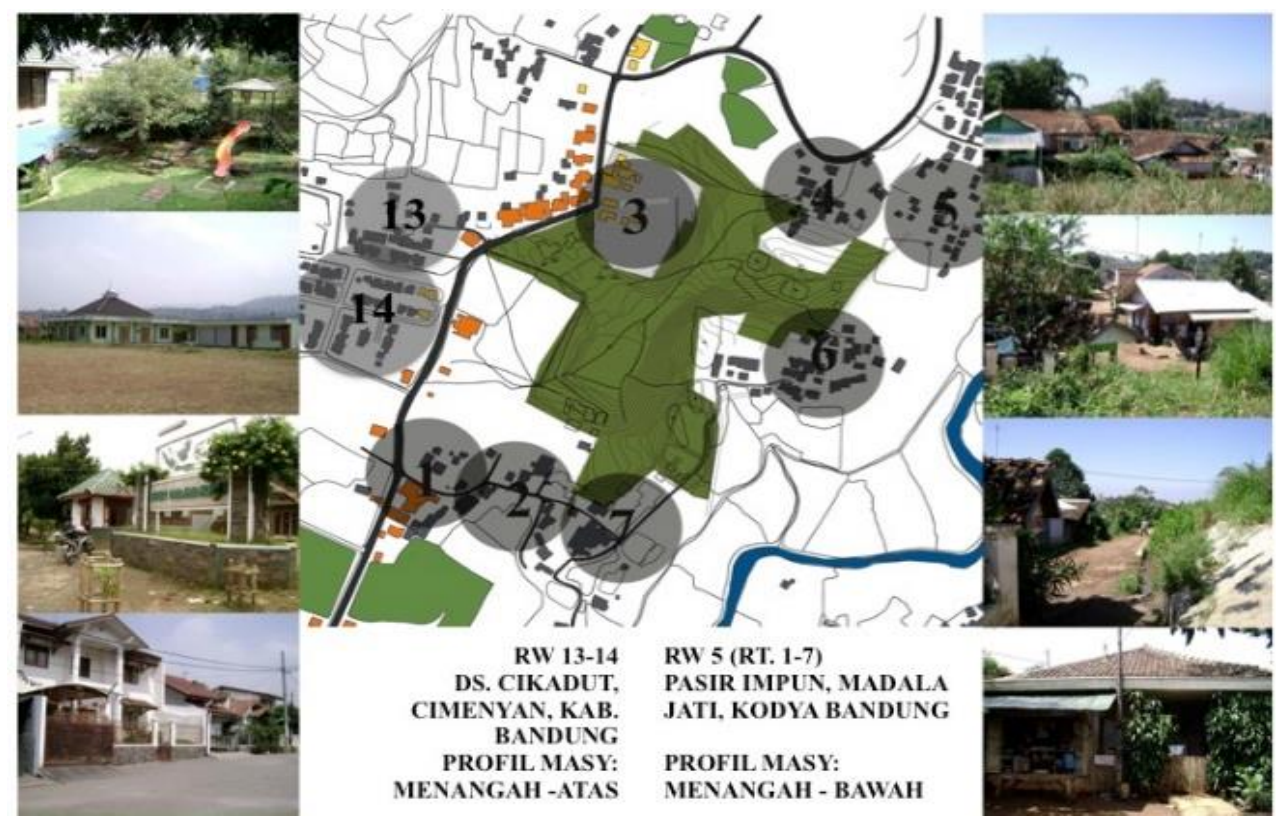

Gambar 9. Kondisi permukiman yang bertetangga dengan lahan TPA

Sumber: Survei lapangan \& Analisis pribadi

Didukung dengan data dari kuesioner yang menyebutkan bahwa 100\% masyarakat tetangga mau datang ke lahan TPA saat ia sudah dialihfungsikan. Semua masyarakat sekitar $(100 \%)$ dan masyarakat umum $(60 \%)$ juga menyebut akan datang ke lahan TPA Pasca Operasi jika sudah 'hijau dan bersih'. Yang perlu dilakukan adalah bagaimana menjadikan lahan TPA Pasca Operasi Pasir Impun sebagai bagian dari keseharian masyarakat sekitar melalui perencanaan yang tepat.

\section{Harapan, Keinginan \& Kebutuhan Masyarakat Terhadap Lahan TPA Pasca Operasi Pasir Impun}

"Parks should meet a variety of needs matched to the demographic characteristics and, more importantly, the expressed desires of community resident."

(Washington State department of Community (2005), Trade and Economic Development: Planning for Parks, Recreation And Open Space in Your Community)

Dari penelitian dapat ditarik kesimpulan bahwa ada 2 (dua) fungsi yang paling diinginkan masyarakat pada lahan TPA Pasca Operasi Pasir Impun, yaitu: fungsi rekreasi dan taman. Jika dilihat dari terminologinya sebenarnya taman dan tempat rekreasi memiliki makna yang identik.

Taman adalah area hijau publik yang cukup luas di kota yang digunakan untuk rekreasi. Sedangkan tempat rekreasi adalah tempat yang dapat digunakan untuk mendapatkan kesenangan (enjoyment), saat seseorang tidak bekerja. Jadi, tempat rekreasi memiliki cakupan makna yang lebih luas. Taman adalah salah satu tempat yang bisa digunakan untuk berekreasi. Sebagai ruang publik, taman harus menampung fungsi yang cukup beragam.

Ragam dan jenis aktivitas baik pasif maupun aktif yang paling diinginkan oleh masyarakat dapat dilihat dalam tabel 2.

Ketiga kelompok masyarakat memilih jalan-jalan sebagai jenis aktivitas aktif yang paling mereka sukai. Sedangkan jenis aktivitas pasif yang jadi favorit dari semua kelompok masyarakat adalah menikmati suasana.

Konsekuensinya, untuk menampung aktivitas yang paling digemari masyarakat yaitu jalan-jalan harus dibuat atau disediakan jalur sirkulasi yang cukup panjang, aman dan nyaman. Keberagaman pengalaman ruang juga harus diciptakan untuk memfasilitasi aktivitas yang paling digemari lainnya, yaitu menikmati suasana. 
Tabel 2. Jenis/ragam aktivitas aktif dan pasif yang diinginkan masyarakat

\begin{tabular}{|c|c|c|c|}
\hline $\begin{array}{l}\text { Kelompok } \\
\text { Masy } \\
\text { Jenis } \\
\text { Aktivitas }\end{array}$ & $\begin{array}{c}\text { Masyarakat } \\
\text { Tetangga }\end{array}$ & $\begin{array}{c}\text { Masyarakat } \\
\text { Sekitar }\end{array}$ & $\begin{array}{l}\text { Masyarakat } \\
\text { Umum }\end{array}$ \\
\hline $\begin{array}{l}\text { Aktivitas } \\
\text { Aktif }\end{array}$ & $\begin{array}{l}\text { - jalan-jalan } \\
(80 \%) \\
\text { - } \text { belanja } \\
(72 \%) \\
\text { - } \text { makan \& } \\
\text { minum } \\
(72 \%)\end{array}$ & $\begin{array}{l}\text { - jalan-jalan } \\
\text { (100\%) } \\
\text { - piknik } \\
\quad(93 \%) \\
\text { - olahraga } \\
(87 \%)\end{array}$ & $\begin{array}{c}\text { - olahraga } \\
(80 \%) \\
\text { - jalan-jalan } \\
(80 \%) \\
- \text { jogging } \\
(70 \%)\end{array}$ \\
\hline $\begin{array}{l}\text { Aktivitas } \\
\text { Pasif }\end{array}$ & $\begin{array}{l}\text { - } \text { menikmati } \\
\text { suasana } \\
(88 \%) \\
\text { - istirahat } \\
\text { (80\%) } \\
\text { - mengamati } \\
\text { sesuatu } \\
(80 \%)\end{array}$ & $\begin{array}{l}\text { - } \text { menikmati } \\
\text { suasana } \\
(73 \%) \\
\text { - mengamati } \\
\text { sesuatu } \\
(73 \%) \\
\text { - istirahat } \\
(67 \%)\end{array}$ & $\begin{array}{l}\text { - } \text { menikmati } \\
\text { suasana } \\
(80 \%) \\
\text { - bercakap- } \\
\text { cakap } \\
(80 \%) \\
\text { - istirahat } \\
(70 \%)\end{array}$ \\
\hline
\end{tabular}

Sumber: Analisis pribadi

Salah satu kriteria keberhasilan ruang publik adalah penyediaan fasilitas yang mendukung aktivitas yang paling diminati. Menurut William $\mathrm{H}$. Whyte, public amenities yang wajib ada dalam sebuah ruang publik, yaitu:

- plaza

- tempat duduk

- lingkungan (pohon, matahari, angin dan air)

- penjual makanan

- hubungan jalan

- triangulasi

Tiga fasilitas yang menurut masyarakat tetangga wajib ada ada dalam lahan nantinya, adalah air, gazebo (saung) dan lapangan olahraga. Sebanyak $84 \%$ masyarakat memilih 3 fasilitas ini. Untuk masyarakat sekitar, 93\% orang menginginkan fasilitas air dan penjual makanan untuk disediakan dalam lahan. Penjual suvenir diinginkan oleh $87 \%$ dari jumlah masyarakat sekitar. Sedangkan masyarakat umum, semua $(100 \%)$ paling menyukai adanya gazebo/saung sebagai salah satu fasilitas yang disediakan di lahan. Air disukai oleh $90 \%$ masyarakat umum pun dengan tempat duduk yang diinginkan oleh $80 \%$ masyarakat umum.

Fasilitas yang sama yang paling diinginkan oleh ketiga kelompok masyarakat adalah air.
Masyarakat umum (36\%) lebih menyukai kolam, sedangkan masyarakat sekitar (4\%) dan masyarakat umum (60\%) lebih menyukai air mancur.

Berikut adalah macam fungsi, aktivitas dan fasilitas yang di-infill, dikembangkan dan dibangun pada lahan TPA Pasca Operasi Pasir Impun:

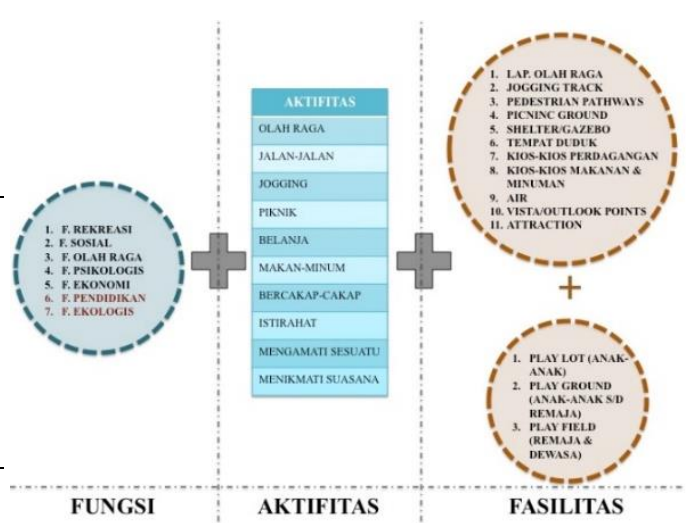

Gambar 10. Macam fungsi, aktifitas dan fasilitas yang akan dikembangkan pada lahan TPA Pasca Operasi Pasir Impun

Sumber: Hasil Analisis

\section{KONSEP DAN HASIL PERANCANGAN RUANG TERBUKA HIJAU}

Pada prinsipnya perancangan lahan haruslah bersifat atraktif dan menarik perhatian, agar terbentuk ruang-ruang yang berkualitas dan identitas lingkungan yang kuat. Hal ini akan menjadi indikator keberhasilan alih fungsi lahan. Karena itu, perumusan prinsip perancangan pada lahan TPA Pasca Operasi Pasir Impun berdasar pada nilai-nilai keberlanjutan atau sustainability karena ujung dari pendekatan partisipasi masyarakat itu adalah terjaminnya keberlanjutan program.

Penjabaran prinsip perancangan RTH pada lahan TPA pasca operasi Pasir Impun, sebagai berikut:

- ekologi, membuat program-program untuk pembangunan aktivitas baru tanpa mengganggu fungsi ekologis lahan sebagai paru-paru kota dan resapan air. 
Perancangan Ruang Terbuka Hijau pada Lahan Tempat Pembuangan Akhir Sampah Pasca Operasi Pasir Impun untuk Membentuk Partisipasi Masyarakat

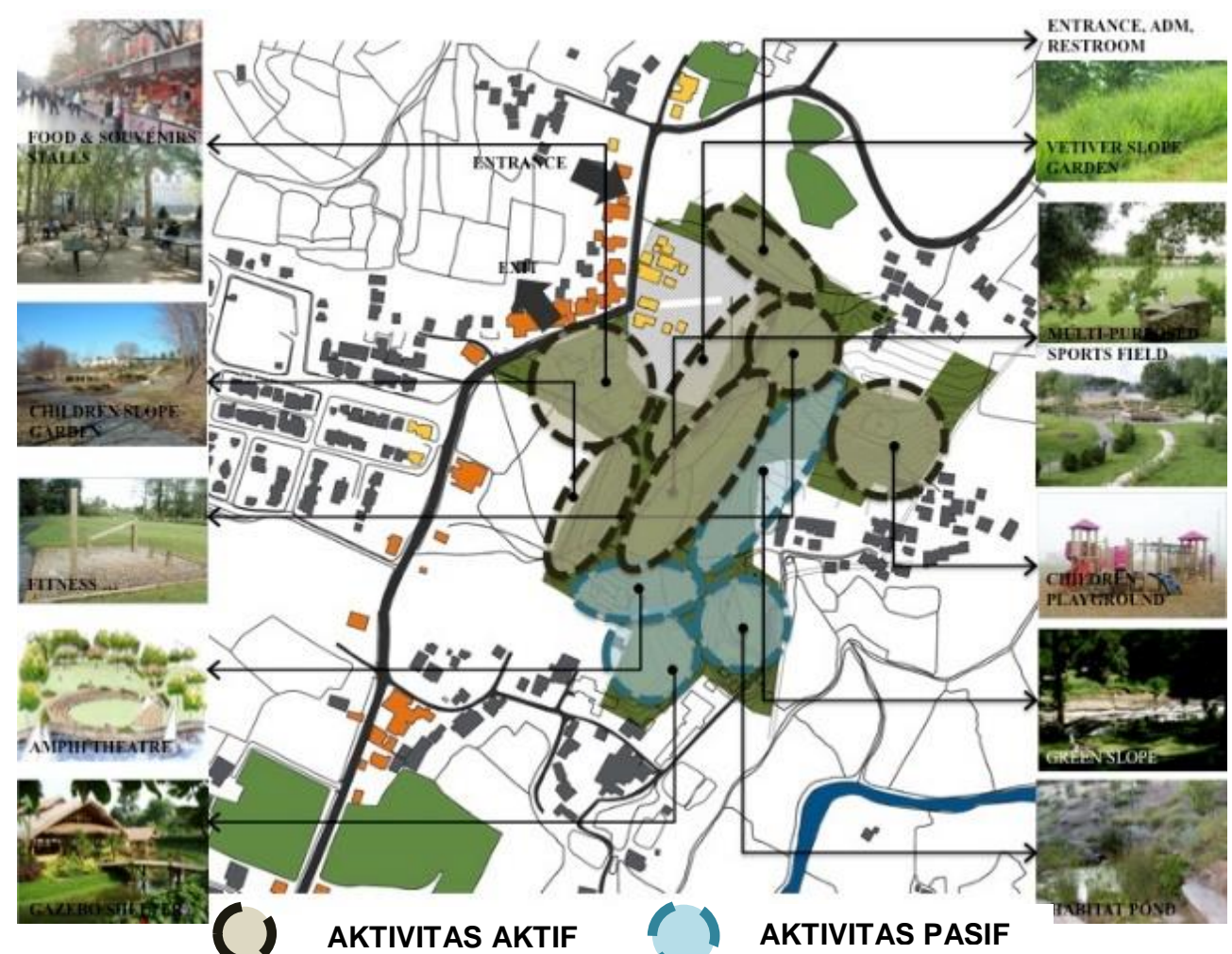

Gambar 11. Penempatan fasilitas dalam lahan merupakan hasil integrasi antara analisa kawasan/tapak dan penelitian persepsi dan harapan masyarakat.

Sumber: Analisis pribadi

- sosial, menciptakan ruang-ruang yang memicu munculnya interaksi sosial yang positif dengan penciptaan suasana yang aktif, edukatif dan rekreatif sebagai usaha untuk menghidupkan lahan. Partisipasi masyarakat dalam pengelolaan, semakin sederhana desain maka pengelolaannya juga akan semakin mudah.
- ekonomi, merupakan faktor yang diperhatikan dalam proses pemograman fungsi, aktivitas dan fasilitas, sehingga lahan bisa menghidupi dirinya sendiri sekaligus memberdayakan masyarakat setempat dalam rangka perbaikan dan peningkatan perekonomian lokal. 


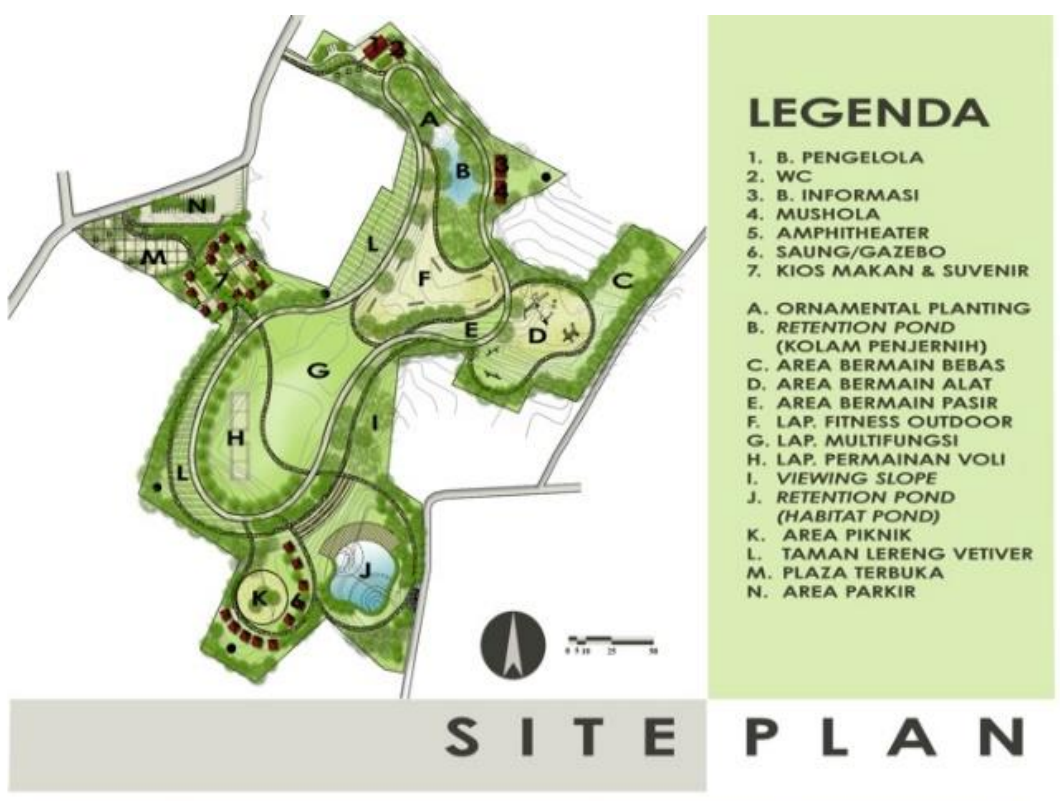

$>$

Gambar 12. Site plan perancangan RTH Taman Lingkungan pada lahan TPA Pasca Operasi Pasir Impun

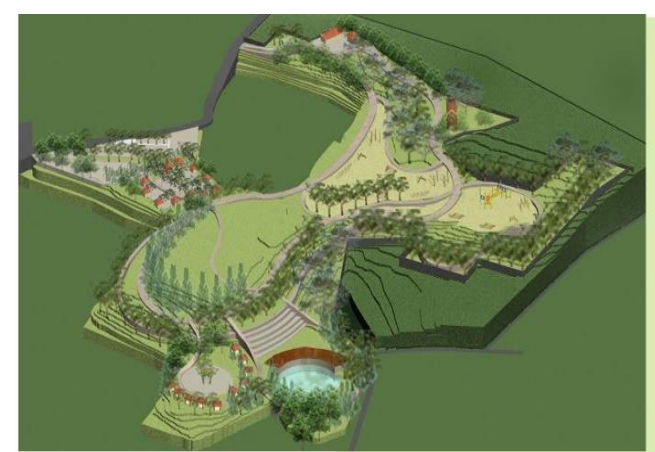

\section{PERSPEKTIF BIRD-EYE (TIMUR - SELATAN)}

Gambar 13. Site plan perancangan RTH Taman Lingkungan pada lahan TPA Pasca Operasi Pasir Impun

\section{Ekologi}

Untuk mewujudkan program-program fasilitas yang telah dibuat, maka dirumuskan konsepkonsep yang selaras dengan hasil analisa yang telah dilakukan sebelumnya. Mengingat lahan merupakan area hijau yang potensial sebagai paru-paru kota, resapan air dan fungsi-fungsi ekologis lainnya maka nilai ekologi merupakan 'payung' besar dari perencanaan pada lahan
TPA Pasca Operasi Pasir Impun. Penerapan konsep ekologi yang diterapkan pada taman dengan cara:

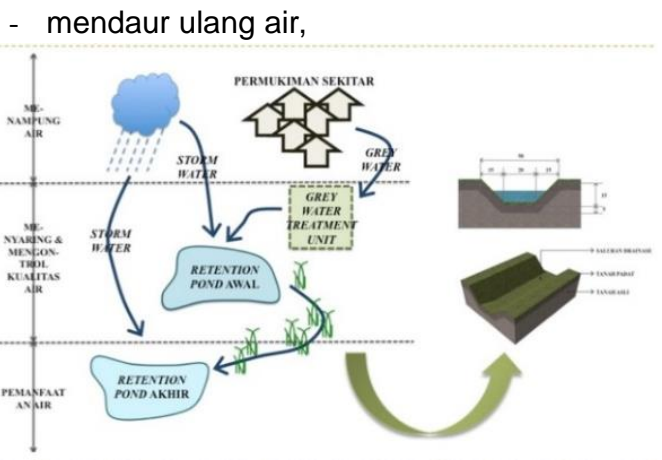

Gambar 14 Prinsip konservasi air pada lahan Sumber: Adaptasi dari Benson, John F., Landscape and Sustainabilty 
Perancangan Ruang Terbuka Hijau pada Lahan Tempat Pembuangan Akhir Sampah Pasca Operasi Pasir Impun untuk Membentuk Partisipasi Masyarakat

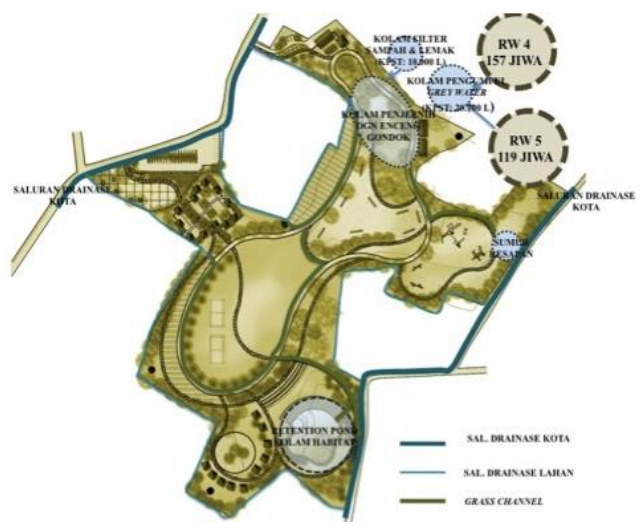

Gambar 15. Rencana drainase lahan

- menstabilkan lahan dengan vegetasi,

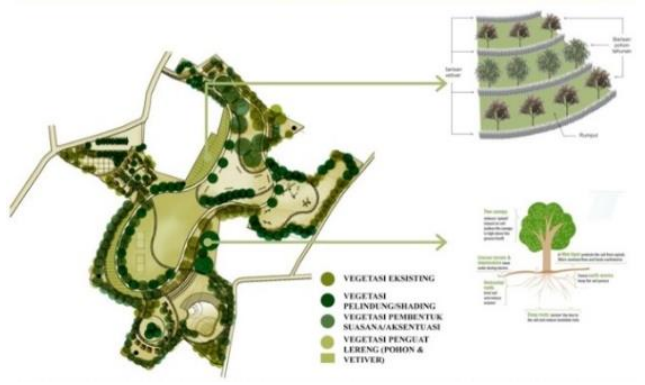

Gambar 16. Konsep vegetasi dan tata hijau

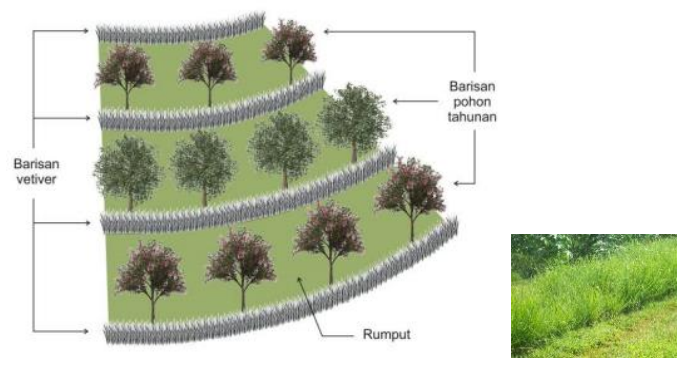

Gambar 17. Penanaman Vetiver pada lereng yang curam

Sumber: Wijayakusuma, Rully, Stabilisasi Lahan dan Fitroremediasi dengan Vetiver System

- mengolah sampah organik (composting)

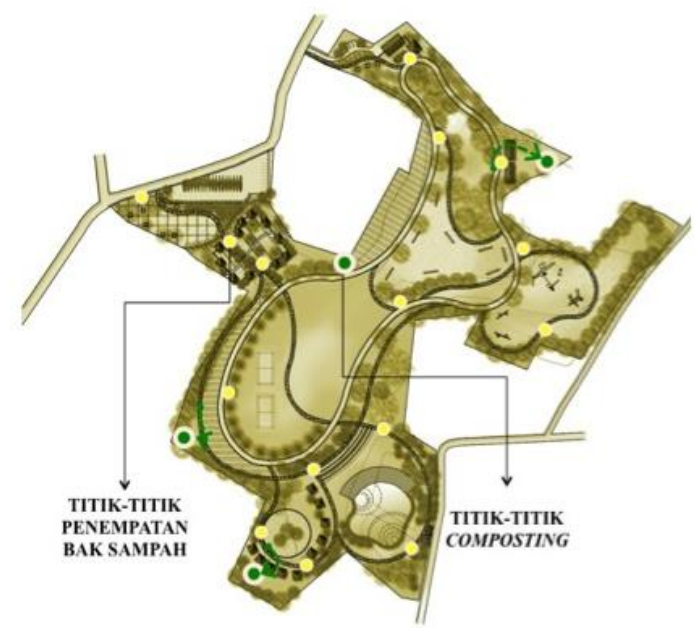

Gambar 18. Titik-titik composting dan penempatan bak sampah dalam lahan

- memanfaatkan energi alam yang tersedia.

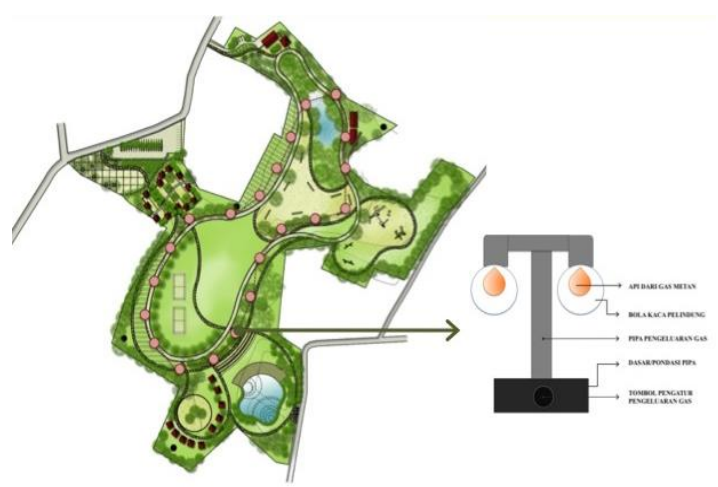

Gambar 19. Desain skematik pemanfaatan pipa gas metan untuk penerangan pada lahan

Penerapan konsep ekologi ini sekaligus merupakan penyelesaian dari kendala teknis yang dihadapi lahan sebagai lahan bekas TPA.

\section{Sosial}

Perancangan lahan memang menitik beratkan pada penciptaan ruang-ruang terbuka dengan mengintegrasikan satu dengan lainnya sehingga merupakan satu kesatuan ruang. Ruang terbuka dirancang bersifat fleksibel, sehingga dapat digunakan untuk beragam fungsi, di antaranya bertemu dan sosialisasi. Masing-masing ruang terbuka yang dirancang memiliki keistimewaan sendiri, sehingga pengalaman ruang yang 
dirasakan di masing-masing ruang terbuka ini akan berbeda-beda.

Ada 6 macam ruang terbuka yang dirancang dalam lahan:

- $\quad$ ruang terbuka hijau untuk edukasi
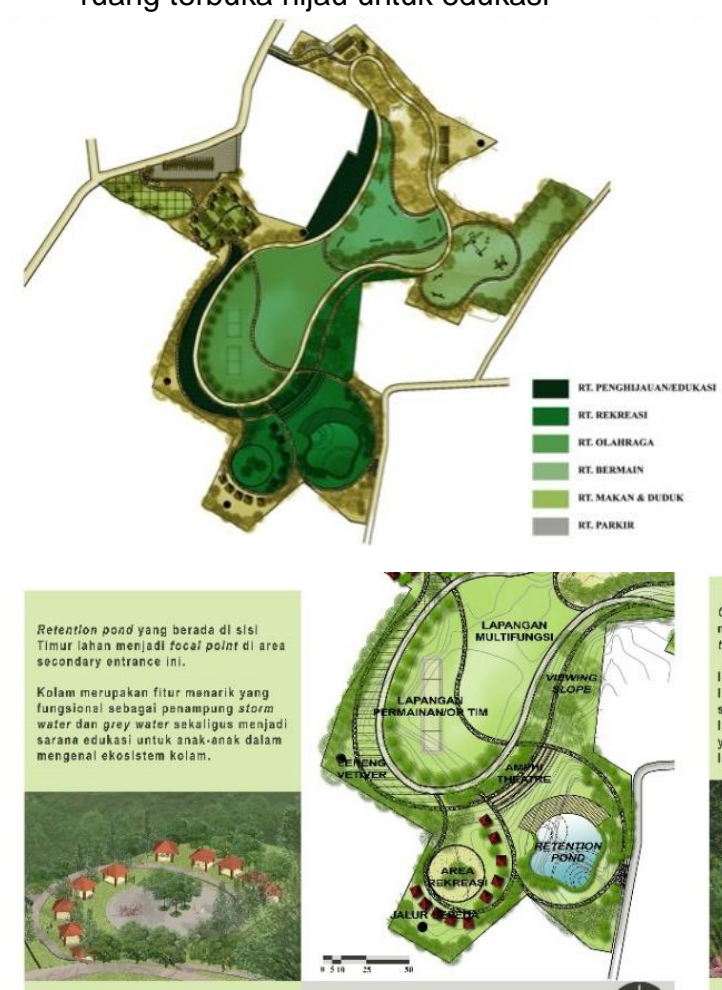

REKREASI
- $\quad$ ruang terbuka untuk rekreasi

- ruang terbuka untuk olahraga

- $\quad$ ruang terbuka untuk bermain

- ruang terbuka untuk duduk-duduk, makan dan belanja

- $\quad$ ruang terbuka untuk parkir

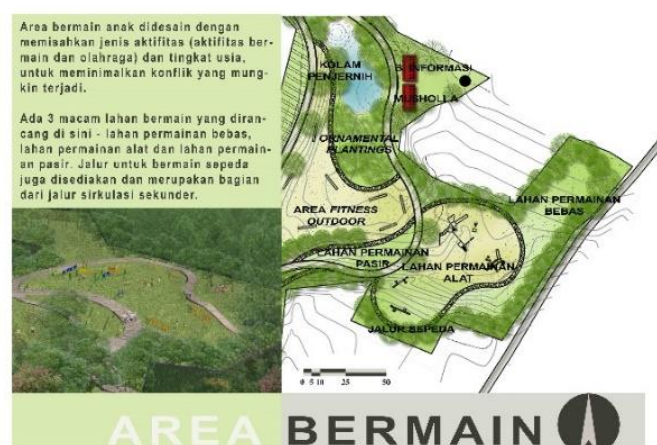

Gambar 20. Konsep area/ruang terbuka

\section{Ekonomi}

Main entrance dibuat di Jl. Pasir Impun dengan pintu masuk dan keluar yang terpisah. Jarak antara keduanya kurang lebih $100 \mathrm{~m}$. Ruas ini direncanakan sebagai koridor komersial. Masyarakat yang bermukim di ruas ini memiliki kesempatan untuk mengembangkan kegiatan perekonomian yang timbul akibat aktivitas yang ada di lahan.

Skenario yang dikembangan di sini, yaitu pengunjung dengan kendaraan memarkir kendaraannya di area parkir yang lokasinya menjadi satu dengan pintu keluar. Untuk menuju pintu masuk, mereka harus melewati ruas jalan sepanjang 100 meter ini yang direncanakan akan dikembangkan menjadi koridor komersial.
Untuk menghidupkan suasana yang lebih festive di koridor ini, maka dilakukan penataan yang meliputi: 


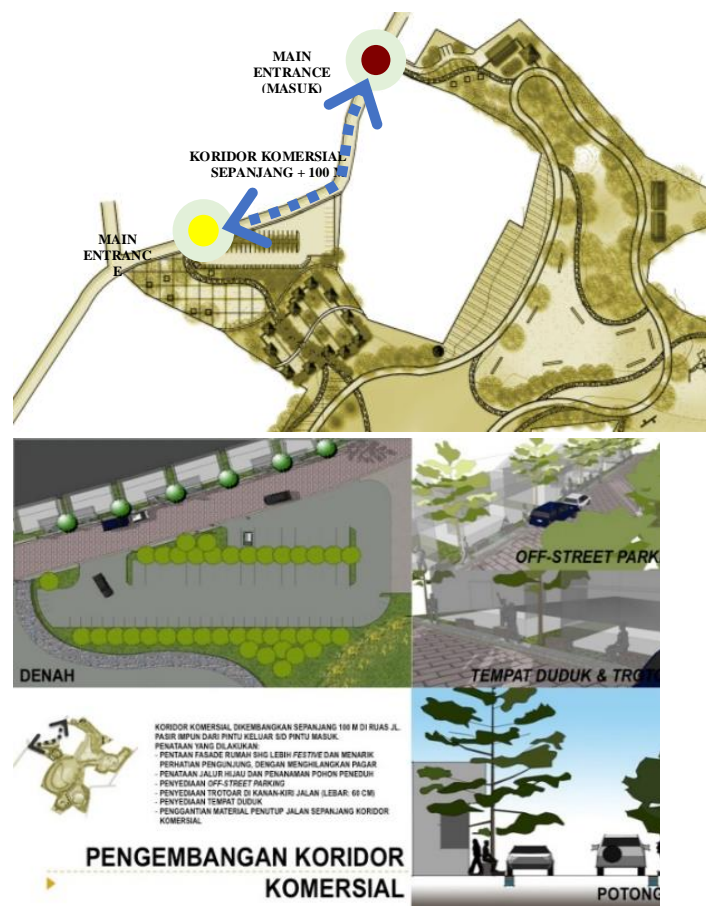

Gambar 21. Pengembangan koridor komersial di Jl. Pasir Impun

- Penambahan jalur hijau dan pedestrian yang dibuat menerus.

Penataan fasade/tampak muka bangunan supaya bisa mengakomodasi kegiatan komersial yang diusahakan warga.

- Jika memungkinkan, menghilangkan pagar pada ruas jalan ini sehingga di dapat jalur hijau dan pedestrian yang lebih luas, serta memungkinkan untuk parkir off-road. Masyarakat pemilik rumah bisa menarik ongkos parkir dari parkir off-road ini sehingga bisa memberi tambahan pendapatan meski hanya terbatas.

- Penambahan fasilitas penerangan yang memadai agar lebih aman.

Penggantian material dan warna jalan di ruas $100 \mathrm{~m}$ ini, sehingga kendaraan yang melintas diharapkan akan mengurangi kecepatannya.

\section{KESIMPULAN}

Dari penelitian dan desain yang telah dilakukan bisa ditarik kesimpulan:

1. Alih fungsi lahan TPA pasca operasi menjadi RTH bisa dilakukan melalui berbagai pendekatan, tergantung dari sisi mana melihatnya, apakah sisi teknis atau sosial.

2. Jika menitikberatkan pada penyelesaian yang terkait dengan permasalahan sosial, maka pendekatan partisipasi masyarakat bisa digunakan.

3. Pendekatan yang lebih berpihak kepada masyarakat dan lebih merespon kebutuhan mereka ini bisa menjamin keberlanjutan program yang direncanakan baik jangka pendek atau panjang.

4. Pendekatan partisipasi masyarakat dengan menempatkan masyarakat sebagai clients dan pengelola dapat digunakan untuk merumuskan fungsi, aktifitas dan kegiatan serta kriteria desain, yang pada akhirnya mempermudah proses perancangan alih fungsi lahan TPA Pasca Operasi Pasir Impun menjadi RTH Kota.

5. Dari pendekatan tersebut didapatkan bahwa bentuk alih fungsi yang paling sesuai adalah menjadikan lahan sebagai taman lingkungan/komunitas, sehingga masyarakat turut aktif dalam pengelolaan.

6. Desain taman lingkungan/komunitas yang dihasilkan adalah ruang publik yang rekreatif-edukatif yang menjadi tempat bersosialisasi bagi masyarakat yang bermukim di sektitarnya.

\section{DAFTAR PUSTAKA}

Benson, John. Roe, Maggie H. 2000. Landscape and Sustainability, London, Spon Press

Carmona, Matthew. Heath,Tim. Oc, Tanner. Tiesdell, Steven. 2003. Public Places, Urban Spaces: The Dimension 
of Urban Design, Oxford, England, Architectural Press

Cumberlidge, Claire. Musgrave, Lucy 2007. Design \& Landscape For People, UK, Thames \& Hudson

Damanhuri, Enri 2008. Diktat Perkuliahan Landfilling Limbah, Bandung, Jurusan TL FTSP ITB

Damanhuri, Enri 1991. Kumpulan Makalah dan Tulisan IImiah, Bandung, Jurusan TL FTSP ITB

Darmasetiawan, Martin; Perencanaan TPA, Jakarta, Ekamitra Engineering

De Chiara, Joseph. Koppelman, Lee A. 1994. Standar Perencanaan Tapak, Jakarta, Erlangga

Departemen PU Dirjen Cipta Karya 2006. Pedoman Pengoperasian dan Pemeliharaan TPA: Sistem Controlled Landfill dan Sanitary Landfill, Jakarta

Departemen PU Dirjen Cipta Karya 2006. Tata Cara Rehabilitasi dan Monitoring Pasca Penutupan TPA Sampah, Jakarta

Fakultas Arsitektur Lansekap dan Teknologi Lingkungan Usakti 2005. Prosiding Seminar Nasional: Pembangunan Lingkungan Perkotaan di Indonesia, Jakarta, FALTL Usakti

Forsyth, Ann. Musacchio, Laura R. 2005. Designing Small Parks: A manual for addressing Social and Ecological Concerns, New Jersey, John Wiley \& Sons

Hakim, Rustam. Utomo, Hardi. (2008); Komponen Perancangan Arsitektur Lansekap: Prinsip-Unsur dan Aplikasi Desain, Jakarta, PT. Bumi Aksara

Harris, Charles W. Dines, Nicholas T. 1998. Time Saver Standards for Landscape Architecture Second Edition, USA, Mc Graw Hill

Irwan, Zoer'aini Djamal. 2005. Tantangan Lingkungan \& Lansekap Hutan Kota, Jakarta, PT. Bumi Aksara

LaGro, James A. 2001. Site Analysis: Linking Program And Concept In Planning And Design, Canada, John Willey \& Sons
Lyall, Sutherland; Designing The New Landscape, London, Thames and Hudson

Marcus, Claire Cooper 1998. People Places, Design Guidelines for Urban Open Spaces, Second Edition, Canada, John Wiley \& Sons

Marsh, William A. 2005. Landscape Planning: Enviromental Application, Fourth Edition, USA, John Willey \& Sons, 93-110

Rapoport, Amos 1977. Human Aspects of Urban Form: Towards a ManEnvironment Approach to Urban Form and Design, Oxford, England, Pergamon Press Ltd.

Riffle, Robert Lee 1998. The Tropical Look: An Encyclopedia of landscape Plants For Worldwide Use, Great Britain, Thames \& Hudson

Stine, Sharon 1997. Landscapes For Learning: Creating Outdoor Environments for Children and Youth, USA, John Willey \& Sons

Sudradjat, Iwan 2002. Diktat Perkuliahan AR 6112: Metodologi Penelitian Arsitektur, Bandung, Program Magister Arsitektur ITB

Walker, Theodore D. Davis, David A. 1990. Plan Graphics Fourth Edition, New York, Van Nostrand Reinhold

Walker, Theodore D. 1991. Planting Design Second Edition, New York, Van Nostrand Reinhold

White, Edward T. 1985. Perencanaan Tapak, Jakarta, Intermatra 